\title{
DECONSTRUCTING DE-GLOBALISATION AS A CHALLENGE USING SAP-LAP ANALYTICAL MODEL: A CASE STUDY OF INDIAN ECONOMY
}

\author{
Dr. Ramandeep Kaur \\ Assistant Professor, \\ Institute of Professional Education and Research
}

\begin{abstract}
In the years prior to 2008, that is before the global financial crisis, emerging market economies saw vigorous global demand, substantial improvements in terms of trade and abundant capital inflows. However, trade growth has been frail, after the financial crisis and whether this movement is permanent or temporary still needs an answer. It has been found that the world is moving, towards the de-globalisation era and the developed nations have marked its instigation. The United States and Britain have adopted the policy leading to the disassembling of the globalisation period and the trend has now been passed on towards India. In the current study, SAP-LAP analytical model has been used to understand the variables that have brought the shift in paradigm towards deglobalisation in India. The objective of the study is to apply SAP-LAP framework to analyse the determinants consisting of 'situation', 'actors' and 'processes' and 'learning', 'action', 'performance' leading to de-globalisation in the Indian context. This modelling technique will help in listing key learning issues and will suggest necessary actions to be taken to improve selected performance areas.
\end{abstract}

Keywords: Globalisation, De-globalisation, SAP-LAP framework, Deconstruct

\section{INTRODUCTION}

In the last quarter of 2008-09 world trade collapsed by about twenty percent as a result of the slowing down of trade liberalization and rising protectionism; it remained one of the most mystifying economic phenomena of the last decade. Throughout the study period, the global economy has grown at an average annual pace of just 2.5 percent; a record low when compared with economic recoils that took place in the decades after World War II. The causes of the current slowdown can be summarized up as the three Ds: Depopulation, Deleveraging, and De-globalization- which is the main focus area of this study.

The rage against globalisation, outsourcing and migration of mining and steel industry jobs to China, South Korea and other parts of Asia is not new. The vote for Britain to exit the European Union, US Presidential Elections 2017, and an unparalleled crumble of China's bubble economy, has been described as the imperative events that brought an end to the era of globalization and which indeed can be seen as a reversal of the globalization process and may even lead the world, to establish a new regime for the global trade currency. A possible reason for this regime, is the thought of concentrating more on inward-looking growth objectives, rather than global growth objectives.

As, the main problem in western economies is the perception that globalization has disadvantaged the middle classes, whose jobs and income have been pushed downward by both migrants- as they are working cheap and by multinationals-as they are offshoring many of their activities to lower cost countries. Thus, the idea of a global world is somewhere being defeated.

From Donald Trump's 'Make America Great Again' to Prime Minister Narendra Modi's 'Make in India', the world leaders are intimating the beginning of de-globalisation era. Visionaries are fore-sighting a new phase of modernism which is driven by economic units that synergise a global, yet de-global network.

According to economist Richard Baldwin, the nature of globalisation has changed. Digital control of supply chains allowed industrial production to be split up into dozens or hundreds of phases, which are then allocated to producers around the globe according to efficiency and cost.

Currently, the evidence of de-globalisation can be found as World trade growth, which easily overtook global GDP growth in last two decades before the crisis, has been expanding at a slower rate than output. Capital flows have fallen steeply. The amount of money crossing-borders is one-third of the level seen before the crisis, this is mainly because banks have restrained their lending, according to McKinsey-Global Institute. However, restriction on excess capital flows were one of the crucial drivers of the crisis, as growth will be detained, if capital cannot move efficiently across borders.

Migration, has also prompted an anti-immigrant repercussion in many countries, and has definitely slowed since the crisis. According to the United Nations, growth in the international migrant stock increased from an average of $2 \%$ a year in $2000-2005$ to $3 \%$ in $2005-2010$, but fell to $1.9 \%$ in $2010-2015$. Also, the World Trade 
A GLOBAL JOURNAL OF SOCIAL SCIENCES

( ISSN - 2581-5830 )

Impact Factor - SJIF - 4.998, IIFS - 4.375

GRAND ACADEMIC PORTAL

RESEARCH JOURNALS

Globally peer-reviewed and open access journal.

Information in euros

Source: OECD, WDI, World Bank

\section{OBJECTIVES OF THE STUDY}

1) To understand the variables that have caused a shift in the paradigm; from globalization to deglobalisation.

2) To apply SAP-LAP analytical model, to analyse its determinants in context with de-globalisation.

3) To enlist key learning issues and suggest corrective actions.

\section{LITERATURE REVIEW}

Globalization can be defined in ways, but is often referred by economists, as the increased movement of goods, capital and workers across national boundaries (see Bardham et al., 2006, or Greico and Ikenberry, 2003).

It is precisely regarded as the source of economic progression and transformation. The transformation can be attributed to the substantial changes in global trade flows accompanied with capital flows and technical advancements across the globe. There have been periods in which globalisation process has been accelerated, supported by technological and policy changes, along with periods of severe slowdowns as an outcome of protectionist strategies and wars. Some historic stages of globalisation are outlined below:

1850-1914: This was a 'golden age' of globalisation, when all markets were free from restrictions, supported by industrialization, urbanisation and new transport and communication systems. Trade reached 38\% of global GDP by 1914, according to Barclays analysis of data- US's National Bureau of Economic Research.

1914-1945: This phase witnessed a sharp slowdown in global trade, declining from 34\% in 1915 to $11 \%$ in 1945. This sharp slowdown is often recognized as an outcome of the two devastating world wars, accompanied with the collapse of the gold standard as an international currency system. The origin of protectionist policies between the two world wars also contributed to the drastic slowdown of global trade.

1945-1990: The third phase of globalisation was made possible by the long economic progressions that followed the end of World War-II. New global economic reforms agreed upon by the United States and its wartime allies in 1944, provided a new framework for international commerce and finance. This period, also witnessed the golden age of capitalism (late 1940s - early 1970s). New international financial agreements and institutions, like: the International Monetary Fund (IMF) and the World Bank, provided a new global financial order and stability.

Post 1990s: The aforesaid period can be regarded as an era of hyper-globalisation and has been witnessing rapid trade integration and growing importance of trade and services, privatisation, deregulation and rapid advances in information and communications technology, also marked by the decease of the Soviet Union. The main beneficiaries were the emerging economies, which became increasingly integrated into complex global value chains (GVCs).

Below Figure III: shows a chart, showing the different stages of globalisation, as economists believe that globalisation goes through cycles and it had appeared to have reached another turning point.

Figure III: Globalisation Cycles

\begin{tabular}{|l|l|l|l|l|}
\hline Duration & Type and Phase & Propeller & Economy & Architecture \\
\hline $1850-1914$ & Globalization-I & Colonization & Boom & Gold Standard \\
\hline $1914-1945$ & De-globalization-I & Protectionism & Slump & Inter-War \\
\hline $1945-1990$ & Globalization-II & Free Trade & Boom & Bretton Woods \\
\hline Post 1990 & $\begin{array}{l}\text { Globalization-III (Hyper- } \\
\text { globalisation) }\end{array}$ & Capital mobility & Slump & Generalized Float \\
\hline
\end{tabular}

Source: NBER Macro-history database, ICICI Bank Research

Renowned economists, Daron Acemoglu and James Robinson believe, that the emergence and survival of democracy depends upon the distribution of income and factor prices. Since poor countries are typically labour abundant, more trade intends to raise wages and lower returns to capital. Thus, if globalization leads to a reduction in the gap among the incomes of the poor and the rich, there should be less political strife because 'the poor have less reason to vote for highly redistributive polices and democracy is less of a threat to the rich' (Acemoglu and Robinson, 2006, p. 322).

While Inglehart/Baker and Acemoglu/Robinson suggests that globalization may be a factor in the global movement towards democratic rule. Marshall and Goldstone (2007a) opines that it may promote instability. The current era of globalization is marked by the increasing number of anocracies, which means that the economies are neither fully consolidated democracies nor full autocracies. Anocracies occupy a middle ground between autocracies and fully-consolidated democracies and more likely to be destabilized by rapid economic and social change; which can be either positive or negative.

Jack Goldstone $(1995,1998,2000,2003,2005)$ and his colleagues on Political Instability and Task Force, have produced enormous research trying to estimate the likelihood of state failure, using the state failure problem 


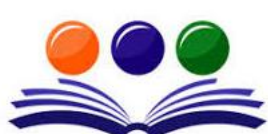

GRAND ACADEMIC PORTAL RESEARCH JOURNALS

A GLOBAL JOURNAL OF SOCIAL SCIENCES

( ISSN - 2581-5830 )

Impact Factor - SJIF - 4.998, IIFS - 4.375

Globally peer-reviewed and open access journal.

set maintained by Monty Marshall and others at the Center for Global Policy- George Mason University. This work has shown that variables measuring economic performance, human welfare, trade openness and regime type are important determinants of the probability of regime failure.

Lastly, there is a large body of literature that relates international trade to inter-state war. In particular, Edward Mansfield (2004) has found 'that there is considerable evidence of an inverse relationship between commerce and war', and 'that higher levels of systemic trade (not necessarily bilateral trade) seem to lead to less likelihood of great power war'. Solomon Polochek (1980) and Erik Gartzke and Quan Li (2003) offer additional empirical evidence for this proposition.

According to Walden Bello, who has infused the term 'de-globalisation', the motive is not to withdraw from the global economy, but to trigger a process of restructuring the world economic and political system, so as to strengthen local and national economies instead of weakening them.

De-globalisation is not a synonym, for withdrawing from the world economy. It means restructuring the world economic and political system, so that the latter builds the capacity of local and national economies instead of degrading them.

Principles of De-globalization specified by Walden Bello (2003) are as follows-

- Production for the domestic market rather than production for export markets must again become the center of gravity of the economy.

- The principle of subsidiarity should be enshrined in economic life by encouraging production of goods at the level of the community and at the national level, if this can be done at reasonable cost in order to preserve community.

- $\quad$ Trade policy - that is, quotas and tariffs - should be used to protect the local economy from destruction by corporate-subsidized commodities with artificially low prices.

- Industrial policy - including subsidies, tariffs, and trade - should be used to revitalize and strengthen the manufacturing sector.

- Long-postponed measures of equitable income redistribution and land redistribution (including urban land reform) must be implemented to create a vibrant internal market that would serve as the anchor of the economy and produce local financial resources for investment.

- De-emphasizing growth, emphasizing upgrading the quality of life and maximizing equity will reduce environmental disequilibrium.

- The power and transportation systems must be transformed into decentralized systems based on renewable sources.

- A healthy balance must be maintained between the country's carrying capacity and the size of its population.

- Environmentally, congenial technology must be developed and diffused in both agriculture and industry.

- A gender lens must be applied in all areas of economic decision making, so as to ensure gender equity.

- Strategic economic decisions must not be left to the market or to technocrats. Instead, the scope of democratic decision-making in the economy should be expanded so that all vital economic issues - such as which industries to develop or phase out, what proportion of the government budget to devote to agriculture, etc. - become subject to democratic discussion and choice. This will entail the demystification of economics and a return to its origins as political economy and moral economy.

- Civil society must constantly monitor and supervise the private sector and the state, a process that should be institutionalized.

- The property complex should be transformed into a 'mixed economy' that includes community cooperatives, private enterprises, and state enterprises, and excludes transnational corporations.

- Centralized global institutions like: the IMF and the World Bank should be replaced with regional institutions, built not on free trade and capital mobility but on principles of co-operation and the logic of capitalism.

The above pointers indicate that, it is more or less, an approach that consciously underlings the logic of the market, the quest of cost efficiency to the values of ecological sustainability, security, equity and social solidarity. Great social democratic scholar Karl Polanyi, describes it as re-embedding the economy in society, rather than having society driven by the economy. 


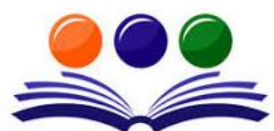

GRAND ACADEMIC PORTAL RESEARCH JOURNALS

A GLOBAL JOURNAL OF SOCIAL SCIENCES

( ISSN - 2581-5830 )

Impact Factor - SJIF - 4.998, IIFS - 4.375

Globally peer-reviewed and open access journal.

\section{SAP-LAP PARADIGM}

SAP-LAP Paradigm is the basis of flexible systems management (Sushil 1997). It considers three basic entities in any management context; situation, actors and process. An interaction of situation, actors and process (SAP) leads to learning, action and performance (LAP); Figure: IV.

SAP-LAP analytical model (Sushil, 2001) is an integrative framework comprising of six basic components:

[1] The 'situation'- which is to be dealt with, that can be external or internal.

[2] The 'actor(s)' dealing with the situation, that can be 'internal' or 'external' with reference to the organization under study.

[3] The 'process (es)' dealing with the situation, which can be 'internal' or 'external' to the organization.

[4] The key 'learning' issues, in terms of the achievement of objectives or problem areas.

[5] The 'action(s)' to be under taken based on learning, affecting the performance areas or objectives.

[6] The 'performance' areas in terms of 'objectives' to be achieved or key result areas (KRAs).

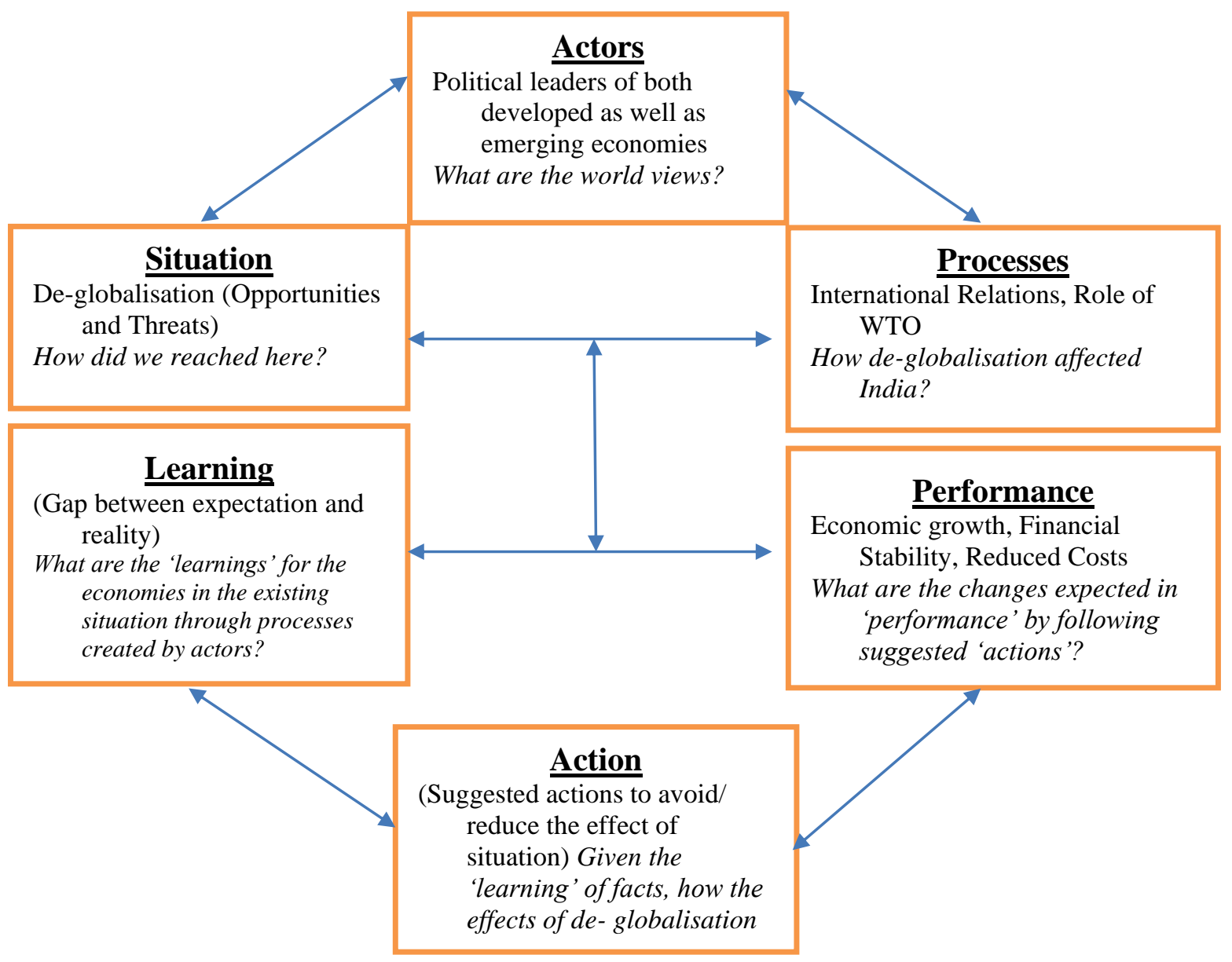

Figure IV: SAP-LAP Analytical Model deconstructing de-globalisation

\section{RESEARCH METHODOLOGY/ DESIGN}

A review of literature has been carried out for better understanding of the challenges and issues involved in deglobalisation. Then, a situation-actor-process (SAP) and learning-action-performance (LAP) analytical model has been applied to deconstruct de-globalisation as a challenge in the Indian context. The situation indicates the present scenario of India. Actors are the participants, influencing the situation to evolve different business processes. Based on SAP, various learning issues have been analyzed which lead to suitable action followed by impact of SAP on performance of India. 


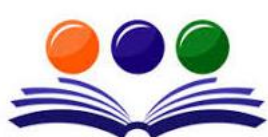

GRAND ACADEMIC PORTAL RESEARCH JOURNALS

Rest of the World: The present discussion about 'trade war' and 'de-globalisation' reaped up after the US, imposed 25 percent and 10 percent tariffs on steel and aluminium imports, respectively, from certain countries, citing national security and job creation as the eliciting causes.

A 25 percent tariff was then imposed on over 1,300 other Chinese products. China hit back by imposing additional tariffs on a range of American imports. The value at stake in the US-China trade wars ranges from \$100-150 billion. The European Union too has jumped into the fray, with a 25 percent duty on certain specific US products. But these tariff wars are only one aspect of de-globalisation policies. With these restrictive tariff plans and hiked import duties, there could be threat to global economic growth, jobs and consumer prices. The coverage of these restrictive trade practices amounts to US\$588 billion, which is seven times larger than last year.

India: When large industrialized and affluent nations focus to impose new entry barriers for goods and services, this can significantly impact the fortunes of their many other trade partners, especially the emerging economies. The value of the rupee dropped to an all-time low in 2018 against US dollars, due to US President Donald Trump's threat of imposing new round of tariffs on imports worth $\$ 200$ billion. Also because of this global trade war, the key indices of the Indian Stock Market also dropped. The US is India's top export partner in goods. Also, India had a trade surplus with the US of \$24 billion in 2016. But, now, The U.S. government has decided to withdraw trade concessions allowed to India under the Generalised System of Preferences (GSP).

Also, India is being accused of imposing restrictive trade policies that burden foreign companies, therefore risk of retaliatory tariffs cannot be ignored, like: in case of Harley-Davidson, import duties on Wine etc. The US economy is India's major market for software services but rising protection has already knocked out Indian IT services, by placing a limit on $\mathrm{H}-\mathrm{IB}$ visas.

India, may not be very much affected by the recent rash of tariffs, as the US derives only a slight percentage of its steel and aluminium imports from India. India has now to pay approx. \$241 million worth of tax to the US. Likewise, India, has proposed imposing duties on 30 different types of goods. This will make sure that the US has to pay about $\$ 238$ million as duties to India. However, this will make things difficult for the end consumers as everything that falls under the tariff scanner is expected to become more expensive.

In case of China, it has cause to fear India's economic expansion, as Indian wages are generally lower than Chinese equivalents, thus keeping the manufacturing cost low. China would explore better relations with India, if in case U.S. tariffs forces, Chinese exporters to depend more on markets outside the United States, then India being a huge market and the fastest-growing economy is a better option. But this could also bring adverse effects on Indian economy, as India has filed the largest number of anti-dumping cases in WTO against China, undermining India's manufacturing sector by dumping cheap, subsidized goods in the Indian market while importing superior raw materials.

\section{ACTORS}

Rest of the World: The increase in the protectionist barriers made governments of diverse nations turn their policies inwards. Focusing on national interest first initiated the campaigns like: for Malaysia, 'the Buy Malaysian campaign', Philippines has 'Buy Filipino campaign', the US has 'Buy American' clause, while China has its 'Made in China 2025' industrial promotion policy in place. Thus, worldwide, an anti-establishment revolt has been raging since the crisis. The major reason behind initiating these campaign is the unequal effects of globalisation. According to Branko Milanovic's 'elephant chart' (2012), the emerging markets' middle class (1 percent) have seen spectacular gains, while the developed markets' middle class (the world's 80th percentile) have remained stagnant for more than two decades.

India: In Indian context, the Indian Government had played a major role in global integration providing a more competitive market for labour and investments. The integration of Asia - especially China and India - has added a large low-cost workforce. Now the capital has more opportunities to grow and get the best returns ever. But, India's trade policy, too, under Prime Minister Narendra Modi's- led government, can also be characterized as a turn back to protectionism after a quarter century or more of trade liberalization; an example to this is the 'Make in India' campaign.

\section{PROCESSES}

Rest of the World: The shift of the economic power from the West to the Asian economies like: India, China and Japan, resulted in frustration, amplified by rising inequality in US. Thus, the period of deep globalisation turned into the risk of de-globalisation. In this background, international relations have rematerialized powerfully. Now, it is not a world of transformed nationalisms, but rather a global juncture, where nations are 


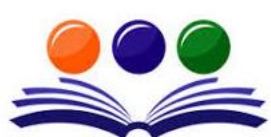

GRAND ACADEMIC PORTAL RESEARCH JOURNALS

A GLOBAL JOURNAL OF SOCIAL SCIENCES

( ISSN - 2581-5830 )

Impact Factor - SJIF - 4.998, IIFS - 4.375

Globally peer-reviewed and open access journal.

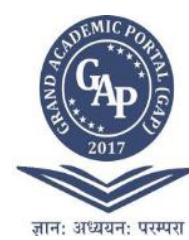

particularly selfish, individualistic, acting according to an 'every nation for itself' concept and distorting the global value chain completely.

In the US-China trade war, the role of World Trade Organisation is also being challenged. Currently, it is facing the most serious threat from the past 70 years for the multilateral trading system. Its role is critically being questioned and therefore there is a need for the WTO to revitalize its dispute settlement mechanism.

India: Earlier, in 1990, just before India started pursuing policies of liberalisation, privatisation and globalisation, its GDP was estimated to be $\$ 326$ billion, whereas that of United States was $\$ 5.9$ trillion. By 2015, India's GDP was $\$ 2$ trillion whereas that of United States was \$18 trillion. In nominal terms, the gap might have increased but in proportional terms, India's growth is significant. In 1990, India's GDP used to be oneeighteenth of the United States' GDP but in 2015 it is one-ninth of the United States. If compared with the UK's economy, the figures are even more surprising. UK's GDP has grown from $\$ 1$ trillion to $\$ 2.8$ trillion in the same time as India has grown from $\$ 326$ billion to $\$ 2$ trillion. Thus, globalisation definitely proved as a boon for the emerging economies.

But, after the financial crisis the restrictive trade policies have drastically affected India, and it is now at the bottom of the 42 countries in the globalization index and with regard to per capita income gains due to globalization. India's GDP gains are low in absolute terms, despite steadily increasing economic integration through the end of the 2000s (Figure I and II).

\section{LEARNING}

Rest of the World: De-globalisation is all about thinking and building alternative integration models with people and resources at the center. According to Walden Bello, the motive is not to withdraw from the global economy, but rather to trigger a process of restructuring the world economic and political system so as to strengthen local and national economies instead of weakening them (Bello, 2005).

The US-China tariff war has contemplated the global economy over the past years and created uncertainty for businesses and consumers. There is also the possibility of goods being diverted on to global markets, producing downward pressure on prices in Europe and elsewhere. Also, this tariff war has established a new and different reality in international trade relations and introduced the businesses to systemic risks. Companies who are entirely dependent on China for sourcing, manufacturing or both find themselves confronting rising costs, fluctuating tariffs, market restrictions and strict regulations along with eroding profits. Firms that ignore these risks or fail to provide appealing contingency plans will be compromising on their long-term survival, growth and financial security.

India: India has progressed considerably along the path of international integration on both trade and finance. Global integration of India is largely beneficial, but should be carefully managed to reap its benefits. India's experience of steady and calibrated capital account liberalization has helped to shield it, to an extent against external shocks, but the events following the Federal Reserve System's (Fed) tapering announcement in 2013 provides that with rising global integration, it is important to build adequate buffers and continue implementing sound economic policies.

With weak growth and an increase in the protectionist sentiments in several advanced economies, policy coordination among the major economies on international trade and finance is likely to become relatively difficult. This implies that emerging economies like: India should rely to a larger extent on domestic sources of growth. Also, policies to enhance India's growth, needs to focus upon, like: financial sector reforms to reduce the NPAs of Indian banks and the related debt projection of firms. This will certainly help in resuming the stuck credit cycle and firms will invest in capacity expansion.

The focus on sustained implementation of productivity enhancing reforms and emphasis on macro-economic stability through prudent monetary and fiscal policies should continue. Over the long term, it is essential that economic growth is made inclusive by broadening access to education, health care and social protection schemes, which will improve productivity and drive future growth in an increasingly sophisticated knowledge economy.

\section{ACTION}

Rest of the World: The de-globalisation framework includes three intimately linked factors. The first is to understand the future of globalisation and its various phases; the second is to deconstruct, confront, resist, slow and obstruct the expansion of globalisation and the third, is to build alternatives to the process of capital capture in the world (Bello, 2005).

There are certain suggestive measures that global businesses can adopt to avoid such situation-

Avoid protectionism and balance globalisation: It is believed that world leaders, especially the G20 forum, should reinforce the WTO rules in trade disputes in order to avoid a reversion in trade and cross-border investment practices.

Compensate the disadvantaged in developed and help developing economies: The reality is that if there is no compensation and empowerment for workers, then the vote for radical or populist substitutions could increase 


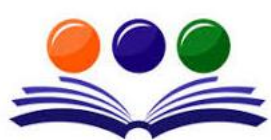

GRAND ACADEMIC PORTAL RESEARCH JOURNALS

A GLOBAL JOURNAL OF SOCIAL SCIENCES

( ISSN - 2581-5830 )

Impact Factor - SJIF - 4.998, IIFS - 4.375

Globally peer-reviewed and open access journal.

and favour protectionism and de-globalisation. Therefore, for the ones who are disadvantaged because of globalisation or those displaced by automation, income-guarantee schemes should be explored.

Education: A complete revamping of the education system is necessary to empower and recycle the skills of individuals throughout their working lives. This should be done through a public-private compact in each country, taking as a good example the German system of dual apprenticeship, and using the new tools enabled by digital technology, which can also be used for more effective influencing by everyone. There should also be more exchange programmes for students worldwide, a global education programme could also bring the world closer together.

Reassurance for the emerging economies: Though it is imperative to address the disruptions caused by globalisation to the semi-skilled lower and middle classes of the developed economies, it is also crucial to allow emerging economies to continue growing further, not only through the expansion of their own internal demand but also through exports; ensuring that the cycle of globalisation continues, with corrections and with sustainability.

India: On the investment front, it is not clear that conventional levers such as interests and tax concessions will be able to stimulate investment to any significant extent. D. Subbarao, former Governor of RBI, argues that in order to minimize the adverse impact of volatile capital flows, central banks in emerging economies should follow a proactive approach. Each policy followed, should be associated with costs. For instance, intervention in foreign exchange market to absorb excess capital flows can have far reaching destabilizing impact on the overall economy. Also the basic amenities in terms of infrastructure should be developed, with further streamlining regulations to ensure ease of doing business. Dealing with automation, poses again an enormous challenge. Here, the policy makers should focus on the scale effects, which means identifying and supporting new activities that can absorb workers and create adequately skilled workers.

In dealing with the political challenges, to challenges of global integration and to study the impact that these factors might have on growth, the safety net considerations can be applied. Components of globalization must be backed up by their positions with credible commitments to a more equitable sharing of the benefits, without derailing the actual process. Further, there has to be a strong co-ordination across countries that have a common motto of sustaining global integration for reaping the benefits and offsetting the costs.

\section{PERFORMANCE}

Rest of the World: According, to Walden Bello, globalisation must be deconstructed, so one can reconstruct integration for the service of humanity. To achieve effective social change, the old systems must be challenged to nutralise their domination.

In order to flourish, the economies should delegitimize and exploit the contradictions and deconstruct both the ideology and the institutions of globalisation governed by the IMF, the World Bank and the WTO. Also, there are certain issues that cannot be governed at the national level alone and needs to be tackled worldwide, such as global terrorism, climate change, corporate transfer pricing, migration, technological disruption and inequality, to name a few. Therefore, alliances, that are convinced that the preservation of a liberal world order, is in the best interest of the economy as a whole should come forward, display mutual cooperation and join hands together.

India: Responding to the threats from declining trade, the dilution of a multilateral framework should divert the focus to meaningful bilateral and regional agreements. India and other Asian countries have the relatively virtuous fortune to be in a 'growth neighbourhood'. Many of the economies in this region, even though growing more slowly than historical standards, are still amongst the fastest growing in the world. Many regional agreements already exist, but countries need to focus on making the most of them, to mutual benefit. As the locus of trade is likely to gear from advanced economies to the neighbourhood, individual economies need to think on how to best utilize their competitive strengths, to cater to new and different markets.

\section{FINDINGS}

Thus, developments in recent years indicate that slowing or even a reversal of global interconnectedness between countries has a negative impact on economic growth of nations.

Developing economies continue to benefit most from globalisation because increasing globalization generates the largest Gross Domestic Product per capita gains for them in absolute terms. The income gap in absolute terms between developed and emerging economies has actually increased. This has increased income inequality and definitely posed a risk for the global economy, as it has led louder calls for protectionist measures in the developed countries that are negatively affected and further it had an adverse impact on all export economies.

The growing popularity of de-globalisation is due to the fact that the benefits of globalisation are not enjoyed by everyone. Therefore, this dissatisfaction has led to growing protectionism.

Further, it is precisely the emerging or developing economies that have achieved, only below average levels in the globalization index, therefore still have great potential to globalize. By doing so, they can generate high 


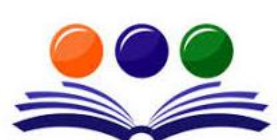

GRAND ACADEMIC PORTAL RESEARCH JOURNALS

\section{A GLOBAL JOURNAL OF SOCIAL SCIENCES}

( ISSN - 2581-5830 )

Impact Factor - SJIF - 4.998, IIFS - 4.375

Globally peer-reviewed and open access journal.

globalization induced growth effects. Therefore, it is essential that developing or emerging economies integrate more into the global economy. In developed industrialized countries, it is essential to spread the benefits of globalization more widely so that social acceptance of a society is not lost.

\section{CONCLUSION}

The global economy has gained some breathing space after the financial crisis of 2008-09, but it faces several threats due to accelerating growth. These threats are structural in nature and needs both strong national responses and effective global co-ordination.

\section{BIBLIOGRAPHY}

[1] Auer, R., Borio, C. and Filardo, A. (2017). The Globalisation of Inflation: the Growing Importance of Global Value Chains. Federal Reserve Bank of Dallas, Globalisation and Monetary Policy Institute Working Papers , 2017(300).

[2] Aggarwal, S. (2017). Smile Curve and its linkages with Global Value chains.

[3] Milanovic, B. (2013). Global Income Inequality in Numbers: in History and Now. Global Policy , 4(2), pp.198 $-208$.

[4] Nber.org. (2019). NBER Macrohistory Database . [online] Available at: http://www.nber.org/databases/macrohistory/contents/

[5] UNCTAD - EORA Global Value Chain Database: methodology and further research agenda. (2015). Transnational Corporations , 2 1(3), pp.57 - 71.

[6] Rungi, A. and Del Prete, D. (2017). 'Smile Curve': Where Value is Added Along Supply Chains. SSRN Electronic Journal.

[7] Banerjee, Abhijit; Deaton, Angus; Lustig, Nora; Rogoff, Ken; Hsu, Edward (2006) An Evaluation of World Bank Research, 1998-2005. Washington, DC: World Bank. https://openknowledge.worldbank.org/handle/10986/17896 License: CC BY 3.0 IGO."

[8] Polanyi, K. (1957) The Great Transformation. Boston: Beacon.

[9] Das, S. (2011) Extreme Money. London: Penguin, pp. 10-11

[10] Anderson, P. (May-Jun 2009) A New Germany? New Left Review 57. Available at https://newleftreview.org/II/57/ perry-anderson-a-new-germany

[11] Keynes, J.M. (1933) “National Self Sufficiency,” Yale Review. https://www.panarchy.org/keynes/national.1933.html

[12] Garg and S. Deshmukh, "Engineering support issues for flexibility in maintenance", Asia Pacific Journal of Marketing and Logistics, Vol. 22, No. 2, 2010 pp. 247-270.

[13] Sushil, "Flowing Stream Strategy: Leveraging Strategic Change with Continuity”, Springer Science \& Business Media, 2012.

[14]DREHER, Alex (2006) 'Does globalization affect growth? Evidence from a new index of globalization.' Applied Economics 38 (10), 1091-1110.

[15] Easterly, W. (2005) 'Reviving the '50s: the big push, poverty traps and takeoffs in economic development, Center for Global Development Working Paper 65, Washington DC.

[16] EATON, Jonathan, Samuel KORTUM, Brent NEIMAN and John ROMALIS (2011) 'Trade and the Global Recession', NBER working paper 16666, NBER: Cambridge MA.

[17] EICHENGREEN, Barry and Douglas A. IRWIN (2009) 'The Slide to Protectionism in the Great Depression: Who Succumbed and Why?', NBER Working paper 15142, NBER: Cambridge, MA.

[18] EICHENGREEN, Barry and Kevin H. O'ROURKE (2009) 'A tale of two depressions', Vox (www.voxeu.org), 1 September.

[19] ESTEVADEORDAL, Antoni, Brian FRANTZ, and Alan M. TAYLOR. (2003) 'The rise and fall of world trade, 1870-1939', Quarterly Journal of Economics, 118 (2), pp. 359-407.

[20]FOUQUIN, Michel and Jule. HUGOT (2016) Two Centuries of Bilateral Trade and Gravity Data: 1827-2014, CEPII working paper 2016-14, CEPII: Paris.

[21] FREUND, Caroline (2009) 'The Trade Response to Global Downturns: Historical Evidence', Policy Research Working Paper 5015, World Bank: Washington DC.

[22] GAWANDE, Kishore, Bernard HOEKMAN, and Yue CUI (2015) 'Global Supply Chains and Trade Policy Responses to the 2008 Crisis.' World Bank Economic Review 29 (1): 102-128. 


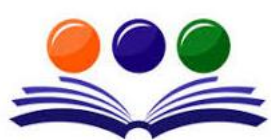

GRAND ACADEMIC PORTAL RESEARCH JOURNALS

\section{A GLOBAL JOURNAL OF SOCIAL SCIENCES}

( ISSN - 2581-5830 )

Impact Factor - SJIF - 4.998, IIFS - 4.375

Globally peer-reviewed and open access journal.

[23] HADDAD, Mona, Ann HARRISON, and Catherine HAUSMAN (2010) 'Decomposing the Great Trade Collapse: Products, Prices, and Quantities in the 2008-2009 Crisis', NBER Working Paper No 16253 NBER Cambridge MA.

[24] HAUGH, David, Alexandre KOPOIN, Ellena. RUSTICELLI, David TURNER and Richard DUTU (2016) Cardiac Arrest or Dizzy Spell Why is World Trade So Weak and What can Policy Do About It? OECD Economic Policy Papers 18 : Paris

[25]HOEKMAN, Bernhard (ed.) (2015) The Global Trade Slowdown: A New Normal? CEPR: www.voxeu.org/sites/default/files/file/Global\%20Trade\%20Slowdown_nocover.p df HONG, Kiseok., Jong.-Wha LEE and Hsiao. C. TANG (2010) 'Crises in Asia: Historical Perspectives and Implication', Journal of Asian Econmics 21 (3), 265-279.

[26] INTERNATIONAL MONETARY FUND (IMF) (2016) World Economic Outlook (WEO) Subdued Demand: Symptoms and Remedies October, IMF: Washington DC.

[27] WORLD BANK (2015) What lies behind the global trade slowdown, Global Economic Prospects, World Bank; Washington DC.

[28] WORLD TRADE ORGANIZATION (2009) World Trade Report 2009 - Trade Policy Commitments and Contingency Measures, WTO: Geneva. 